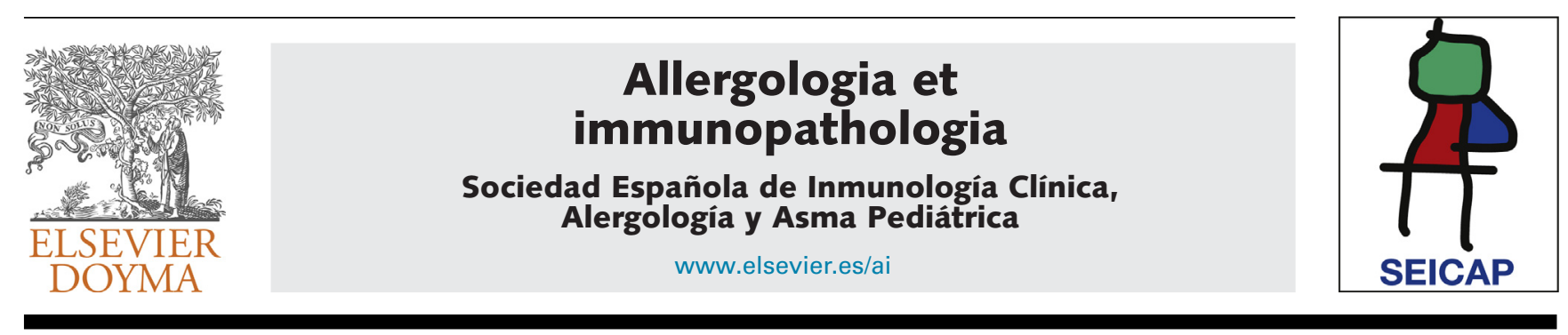

RESEARCH LETTER

\section{Successful oral tolerance induction to cow's milk in a child with allergy to extensively hydrolysed formula}

\section{To the Editor,}

Cow's milk allergy (CMA) is the most frequent food allergy in childhood. ${ }^{1}$ Treatment consists of cow's milk proteins eviction, with the use of an extensively hydrolysed milk formula (eHF) being the first option in most cases, due to its good tolerance, availability and cost. ${ }^{1}$ Few cases of IgE-mediated allergy to eHF have been reported ${ }^{2-6}$ but oral tolerance induction (OIT) has not been previously described in children with allergy to eHF.

We report the case of a boy, referred to our Immunoallergy department in 2010, at the age of five years, whose parents reported a severe IgE-mediated CMA diagnosed at six months of age following an episode of anaphylaxis, with generalised urticaria, angio-oedema, rhinoconjunctivitis and wheeze after yoghourt ingestion, and vomiting after eating a milk-containing puree. The child began cow's milk avoidance and was started on an eHF (Aptamil ${ }^{\circledR}$ Pepti Junior, Milupa). However, several episodes of reproducible urticaria occurred immediately after eHF introduction, for which it was stopped and a soy milk formula was prescribed. At that time the child had specific IgE (ImmunoCAP ${ }^{\circledR}$, Phadia - Thermo Fisher Scientific, Uppsala, Sweden) positive for whole cow's milk $(55.2 \mathrm{kU} / \mathrm{L})$, casein $(54.8 \mathrm{kU} / \mathrm{L}), \beta$ lactoglobulin (BLG) $(16.6 \mathrm{kU} / \mathrm{L})$ and $\alpha$-lactalbumin (ALA) $(42.9 \mathrm{kU} / \mathrm{L})$, and negative for soy. Due to food proteininduced enterocolitis syndrome with soy milk, manifesting as recurrent diarrhoea beginning three weeks after soy milk introduction, the child was started on an aminoacid formula (Neocate ${ }^{\circledR}$, Nutricia), which he maintained at the time of the consultation with good tolerance and adequate growth. The parents reported several episodes of contact urticaria on occasional mucocutaneous contact with cow's milk, and no episodes of accidental cow's milk ingestion.

The child also presented with symptoms of asthma since early childhood, controlled with inhaled fluticasone through a spacer device, mild persistent rhinitis treated with nasal mometasone furoate, mild atopic dermatitis and a family history of atopy (father and brother with asthma and rhinitis).
Skin prick tests (SPT) (Laboratorios Leti, Madrid, Spain) at the age of five years were positive for whole cow's milk (mean wheal diameter $=9 \mathrm{~mm})$, casein $(10 \mathrm{~mm})$, BLG $(9 \mathrm{~mm})$, ALA $(8 \mathrm{~mm})$ and eHF (Aptamil ${ }^{\circledR}$ Pepti Junior, Milupa) $(8 \mathrm{~mm})$. As a control, due to the fact that the SPT with eFH is not standardised, we performed SPT with this eHF in 10 CMA children, which was negative in all of them. SPT were negative for aeroallergens and soy extract. Specific IgE (ImmunoCAP ${ }^{\circledR}$, Phadia - Thermo Fisher Scientific) was positive for whole cow's milk $(36.0 \mathrm{kU} / \mathrm{L})$, casein $(33.4 \mathrm{kU} / \mathrm{L})$, BLG (12.3 kU/L) and ALA (22.1 kU/L).

At the age of six years, an open oral provocation test with cow's milk was performed, which was positive 17 min after ingestion of $1 \mathrm{~mL}$ of cow's milk, with generalised urticaria, rhinoconjunctivitis and palpebral oedema. The child presented no respiratory, gastrointestinal or cardiovascular symptoms and was treated with oral antihistamine and corticosteroid with complete resolution in $3 \mathrm{~h}$.

Due to the persistence of cow's milk allergy at the age of six years, an oral tolerance induction (OTI) procedure was proposed and consented by the parents, which was completed in 30 weeks (Table 1). Since then, the child maintains a daily intake of $200 \mathrm{~mL}$ once a day, with progressive introduction of other milk containing foods with tolerance.

Skin prick tests four weeks after OIT were positive for cow's milk $(4 \mathrm{~mm})$, casein $(4 \mathrm{~mm})$, BLG $(5 \mathrm{~mm})$ and ALA $(3 \mathrm{~mm})$ and negative for eHF. Skin prick tests one year after OIT were positive for casein $(3 \mathrm{~mm})$, BLG $(4 \mathrm{~mm})$ and ALA $(3 \mathrm{~mm})$ and negative for cow's milk. Data on specific IgE and $\operatorname{lgG}_{4}$ before, during and after OIT are presented in Table 2.

\section{Comments}

Milk allergens are known to preserve their biological activity even after boiling, pasteurisation, ultra-high temperature processing or evaporation, which is the reason why extensive hydrolysis is necessary to obtain hypoallergenic formulas (1); eHFs can be produced from casein or whey proteins and have been characterised as those in which $\geq 95 \%$ of peptides have a molecular weight $<1500 \mathrm{Da}$ and less than $0.5 \%$ have a molecular weight $>6000 \mathrm{Da}(2)$, although there is no agreement on these criteria. ${ }^{1}$

Allergic reactions, IgE and non-IgE mediated, to both casein and whey protein eHFs, have been previously reported (2-6). Our patient presented with anaphylaxis to cow's milk and urticaria to an extensively hydrolysed whey

0301-0546/\$ - see front matter @ 2013 SEICAP. Published by Elsevier España, S.L. All rights reserved. http://dx.doi.org/10.1016/j.aller.2013.11.005 
Table 1 Cow's milk oral tolerance induction protocol.

\begin{tabular}{|c|c|c|c|c|c|c|}
\hline Visit 1 (Day 1) & $\begin{array}{l}\text { Visit } 2 \\
\text { (Day 27) } \\
\text { Week } 3\end{array}$ & $\begin{array}{l}\text { Visit } 3 \\
\text { (Day 76) } \\
\text { Week } 10\end{array}$ & $\begin{array}{l}\text { Visit } 4 \\
\text { (Day 104) } \\
\text { Week } 14\end{array}$ & $\begin{array}{l}\text { Visit } 5 \\
\text { (Day 125) } \\
\text { Week } 17\end{array}$ & $\begin{array}{l}\text { Visit } 6 \\
\text { (Day 181) } \\
\text { Week } 25\end{array}$ & $\begin{array}{l}\text { Visit } 7 \\
\text { (Day 216) } \\
\text { Week } 30\end{array}$ \\
\hline \multicolumn{7}{|c|}{ Dose increase at the hospital } \\
\hline 1 drop & $0.5 \mathrm{~mL}^{\mathrm{a}}$ & $5 \mathrm{~mL}^{\mathrm{a}}$ & $20 \mathrm{~mL}^{\mathrm{a}}$ & $30 \mathrm{~mL}^{\mathrm{a}}$ & $50 \mathrm{~mL}^{\mathrm{a}}$ & $100 \mathrm{~mL}$ \\
\hline 2 drops & $0.5 \mathrm{~mL}$ & $5 \mathrm{~mL}$ & $20 \mathrm{~mL}$ & $30 \mathrm{~mL}$ & $50 \mathrm{~mL}$ & $100 \mathrm{~mL}$ \\
\hline 3 drops & $1 \mathrm{~mL}^{\mathrm{b}}$ & $10 \mathrm{~mL}$ & $30 \mathrm{~mL}^{\mathrm{b}}$ & $30 \mathrm{~mL}$ & $50 \mathrm{~mL}$ & ( $2 h$ interval) \\
\hline 4 drops & $1 \mathrm{~mL}$ & $10 \mathrm{~mL}$ & (2h interval) & ( $2 h$ interval) & (2h interval) & $200 \mathrm{~mL}$ \\
\hline $0.1 \mathrm{~mL}$ & $5 \mathrm{~mL}$ & $20 \mathrm{~mL}^{\mathrm{b}}$ & $30 \mathrm{~mL}$ & $50 \mathrm{~mL}$ & $100 \mathrm{~mL}$ & \\
\hline $0.2 \mathrm{~mL}^{\mathrm{b}}$ & (2h interval) & ( $2 \mathrm{~h}$ interval) & & & & \\
\hline $\begin{array}{l}0.5 \mathrm{~mL}^{\mathrm{b}} \\
\text { (2h interval) } \\
0.5 \mathrm{~mL}\end{array}$ & $5 \mathrm{~mL}$ & $20 \mathrm{~mL}$ & & & & \\
\hline \multicolumn{7}{|c|}{ Maintenance dose at home after the visit ${ }^{\complement}$} \\
\hline $0.5 \mathrm{~mL}$ bid $^{\mathrm{d}}$ & $5 \mathrm{~mL}$ bid & $20 \mathrm{~mL}$ bid $^{\mathrm{e}}$ & $30 \mathrm{~mL}$ bid & $50 \mathrm{~mL}$ bid & $100 \mathrm{~mL}$ bid & $200 \mathrm{~mL}$ id \\
\hline \multicolumn{7}{|c|}{$\begin{array}{l}\text { OIT initiated with sublingual drops with } 20 \text {-min interval. Oral doses with } 30 \text {-min interval between intakes, except when specified } \\
\text { otherwise. } \\
\text { a Cow's milk intake done at home before the visit. } \\
\text { b Allergic reaction (cutaneous erythema and rhinitis), self-limited, without medication needed. } \\
\text { c After a meal (breakfast/dinner) and advised to avoid vigorous exercise in the two subsequent hours, bid: twice a day, id: once a day. } \\
\text { d } 2 \text { reactions of rhinoconjunctivitis and } 1 \text { of facial and trunk urticaria at home, within } 15 \text { min after milk intake, self-limited. } \\
\text { e } 1 \text { reaction at home } 5 \text { min after intake, with headache and facial urticaria, treated with oral antihistamine and corticosteroid. }\end{array}$} \\
\hline
\end{tabular}

protein formula due to an IgE-mediated mechanism, confirmed by skin prick test positivity.

Although CMA is mainly due to the IgE binding to conformational epitopes, Matsumoto et al. ${ }^{7}$ have demonstrated the lgE binding to linear epitopes from caseins and also from whey proteins such as ALA and BLG and that the pattern of IgE and IgG4 reactivity to these epitopes could differentiate sensitisation from transient and persistent CMA. Moreover, despite extensively hydrolysed casein formula showing a better safety profile than that of whey hydrolysates, ${ }^{3}$ it still contains trace amounts of casein and whey, ${ }^{8}$ which may be responsible for the clinical reactivity in some patients.

No previous studies have compared children's allergy and tolerance to eHF in relation to severity and duration of CMA, or to values of specific IgE or skin prick tests to cow's milk and proteins, but one might hypothesise that allergy to eHF could be a marker of severity, since children react to linear epitopes and/or to trace amounts of cow's milk proteins, which is also consistent with the high specific IgE found in our patient prior to OIT.
García-Ara et al. ${ }^{9}$ have reported that milk OIT is achieved earlier in children with low specific IgE and that those allergic children with higher cow's milk specific IgE levels $(>11.4 \mathrm{kU} / \mathrm{L})$ experience more frequent and severe adverse reactions during the procedure. Morais-Almeida et al. ${ }^{10}$ have reported achievement of a $200 \mathrm{~mL}$ maintenance dose in a mean of four (from 3 to 6) hospital visits and 12 (from 6 to 20) weeks in children with anaphylaxis to cow's milk, using the same OIT protocol, with $2 / 10$ children presenting anaphylactic reactions and $8 / 10$ children presenting a total of 13 mild to moderate reactions treated with oral antihistamines or corticosteroids during induction phase. This is in contrast with the longer period of time ( 30 weeks) and number of visits (seven visits) needed to achieve tolerance in the reported patient and to the more frequent adverse reactions, although all the reactions were mild to moderate (five reactions at the hospital and four at home).

To the best of our knowledge, this is the first report of a patient with eHF allergy treated with OIT. We emphasise that despite OIT taking a longer time and with more adverse

Table 2 Specific IgE (kU/L) and IgG4 (mg/L) to cow's milk and cow's milk proteins before, during and after oral tolerance induction.

\begin{tabular}{|c|c|c|c|c|c|c|}
\hline \multirow[t]{2}{*}{$\operatorname{lgE} / \lg G 4$} & \multirow[t]{2}{*}{ Before OIT } & \multicolumn{2}{|l|}{ During OIT } & \multicolumn{3}{|l|}{ After OIT } \\
\hline & & Week 12 & Week 28 & Week 4 & 6 months & 1 year \\
\hline Cow's milk & 13.3/ND & $12.9 / 25,433$ & $5.38 />30,000$ & $6.99 />30,000$ & $3.53 />30,000$ & $2.76 />30,000$ \\
\hline Casein & $12.2 / 884$ & $6.82 / 15,047$ & $5.35 />30,000$ & $3.51 />30,000$ & $3.15 />30,000$ & $2.12 />30,000$ \\
\hline BLG & $3.7 / 1021$ & $5.65 / 7773$ & $3.37 />30,000$ & $2.74 />30,000$ & $2.19 />30,000$ & $1.59 />30,000$ \\
\hline ALA & $4.59 / 446$ & $10.4 / 26,926$ & $5.64 />30,000$ & $4.82 />30,000$ & $2.35 />30,000$ & $2.02 />30,000$ \\
\hline
\end{tabular}

ND, not done. 
events than previously reported by the authors, ${ }^{10}$ tolerance of $200 \mathrm{~mL}$ of cow's milk plus a free diet was achieved and a decrease of specific lgE/lgG4 ratio as well as in skin prick test size to whole cow's milk and its proteins was observed. Moreover, the previously positive skin prick test to the eHF turned negative after successful OIT.

\section{Ethical disclosures}

Protection of human and animal subjects. The authors declare that no experiments were performed on humans or animals for this investigation.

Confidentiality of data. The authors declare that they have followed the protocols of their work centre on the publication of patient data and that the parents of the patient included in the study have received sufficient information and have given their informed consent in writing to participate in that study.

Right to privacy and informed consent. The authors have obtained the informed consent of the parents of the patient mentioned in the article. The author for correspondence is in possession of this document.

\section{References}

1. Fiocchi A, Brozek J, Schünemann H, Bahna SL, von Berg A, Beyer $\mathrm{K}$, et al. World Allergy Organization (WAO) diagnosis and rationale for action against cow's milk allergy (DRACMA) guidelines. Pediatr Allergy Immunol. 2010;21 Suppl. 21:1-125.

2. Sampaio G, Romeira AM, Arêde C, Prates S, Pires G, MoraisAlmeida $M$, et al. Extensively hydrolyzed formulas allergy - 3 clinical reports. Rev Port Imunoalergol. 2003;11:41-5.
3. Caffarelli C, Plebani A, Poiesi C, Petroccione T, Spattini A, Cavagni G. Determination of allergenicity to three cows milk hydrolysates and an amino acid derived formula in children with cow's milk allergy. Clin Exp Allergy. 2002;32:74-9.

4. Nilsson C, Oman H, Hallden G, Lilja G, Lundberg M, Harfast B. A case of allergy to cow's milk hydrolysate. Allergy. 1999;54:1322-6.

5. Ragno V, Giampietro PG, Bruno G, Businco L. Allergenicity of milk proteins hydrolysate formula in children with cow's milk allergy. Eur J Pediatr. 1993;152:760-2.

6. Businco L, Cantani A, Longhi MA, Giampietro PG. Anaphylatic reactions to a cow's milk whey hydrolysate (Alfa-Ré Nestlé) in infants with cow's milk allergy. Ann Allergy. 1989;62:333-5.

7. Matsumoto N, Okochi M, Matsushima M, Kato R, Takase T, Yoshida $Y$, et al. Peptide array-based analysis of the specific IgE and IgG4 in cow's milk allergens and its use in allergy evaluation. Peptides. 2009;30:1840-7.

8. Hoffman KM, Sampson HA. Serum specific-IgE antibodies to peptides detected in casein hydrolysate formula. Pediatr Allergy Immunol. 1997;8:185-9.

9. García-Ara C, Pedrosa M, Belver MT, Martín-Muñoz MF, Quirce S, Boyano-Martínez T. Efficacy and safety of oral desensitization in children with cow's milk allergy according to their serum specific IgE level. Ann Allergy Asthma Immunol. 2013;110:290-4.

10. Morais-Almeida M, Piedade S, Couto M, Sampaio G, Santa-Marta C, Gaspar A. Innovation in specific oral tolerance induction in children with anaphylaxis to cow's milk proteins. Rev Port Imunoalergol. 2011;19:161-9.

N. Santos, A. Gaspar*, L.M. Borrego, M. Morais-Almeida Immunoallergy Department, CUF Descobertas Hospital, Lisbon, Portugal

* Corresponding author.

E-mail address: angela.gaspar@sapo.pt (A. Gaspar). 